\title{
Demarcation of groundwater potential zones in Amravati River Basin, Maharashtra using Analytical Hierarchical Process and Geospatial Techniques
}

\author{
Dr. Satish P. Patil \\ SVS's Dadasaheb Rawal College, Dondaicha. Dist. Dhule, Maharashtra (India).
}

\begin{abstract}
Abstact: In the present study, a challenge is made to delineate groundwater potential zones in Amravati River Basin using remote sensing, GIS, and Analytical Hierarchical Process (AHP). Manifold data, viz. lithology, lineament density, geomorphology, slope, soil, rainfall, drainage density, relief, land-use/landcover were considered for delineating the groundwater potential zones. All thematic layers were organized using remote sensing data on ArcGIS 10.8.1 platform. Next, weights were allocated to different layers and the features within them using a pairwise comparison matrix through the AHP. The weights attained were tested for their uniformity using the consistency index and consistency ratio. A final weighted map was then prepared by multiplying each thematic layer's weights with the weights of features within them and adding them. Built on this final weighted layer, the basin was categorized into very poor, poor, moderate, good, very good groundwater potential zones. The maximum area $(26.75 \%)$ is under the poor groundwater potential zone followed by the moderate zone (21.37\%), very poor $(21.43 \%)$, good $(15.70 \%)$, very good $(14.76 \%)$. Sensitivity analysis using the map removal method is performed to assess the most influential parameters, geology, geomorphology, lineament density are the most influential. General results prove the effectiveness of the use of geospatial technology in combination with AHP in the delineation of underground water potential zones.
\end{abstract}

Keywords: Consistency ratio, Groundwater, Analytical Hierarchical Process, GIS

\section{INTRODUCTION}

Groundwater is a valuable resource that's why it is the key source for industries, communities, agricultural consumption in the world. Currently, about $34 \%$ of world's water resources have its place to groundwater and are an important source of drinkable water. In India similarly groundwater has arisen as the backbone of its agriculture and drinking water security. The influence of groundwater is nearly $62 \%$ in irrigation, $85 \%$ in rural water supply, $45 \%$ in the urban water supply (Saha and Ray, 2019). However, due to fiery population growth, expansion of agricultural activities, and huge industrialization, there has been an intermittent increase in water demand. This has led to irresponsible water exploitation, mainly groundwater in different parts of the country, altering them into water dark zones. Less than 600 million people in India are underneath water-stressed conditions (Niti Aayog Report, 2018). Assessment of groundwater potential is a challenging task as it requires all recharge and discharge parameters to be surely evaluated (Kumar et al., 2019). Traditional methods of groundwater data collection include considerable time, money, and manpower. However, automated methods using Remote Sensing and GIS have emerged as effective tools for measuring various groundwater characteristics by providing systematic, synoptic, rapid, and excellent configuration to holder large and complex spatial data (Yeh et al., 2016; Gnanachandrasamy et al., 2018). Numerous methods and models like probabilistic models such as frequency ratio, multi-criteria decision analysis, weights of evidence, logistic regression, etc. are used to delineate potential groundwater zones (Arulbalaji et al., 2019). Amongst these Analytical Hierarchical Process is widely used to delineate potential groundwater zones (Rajasekhar et al., 2019; Dar et al., 2020; Kindie et al., 2019; Mallick et al., 2019; Roy et al., 2019) In the present study, the Analytical Hierarchical Process is used to demarcate potential water zones in the Amravati River basin. Its first objectives are demarcation of various attributes viz. geology, geomorphology, relief etc., second, delineation of groundwater potential zones.

Numerous factors influence the behaviour and movement of underground water. Their influence varies from region to region; hence their finest selection is of greatest importance for proper delineation of potential groundwater zone. Their choice depends upon the purpose of study, the nature of the region, their accessibility. Considering the nature of the basin under study and extensive literature review (Mukherjee and Singh, 2020; Muralitharan and Palanivel, 2015; Murmu et al., 2019; Arulbalaji et al., 2019; Kumar and Krishna, 2018), nine parameters viz. geology, geomorphology, rainfall, slope, Land use/land cover, relief, drainage density have been considered. Local hydrogeology plays a vital role in the existence of groundwater and its spatial distribution. The water holding capacity and recharge/discharge 


\section{DOI: $10.17148 /$ IARJSET.2021.81115}

capability of a geological formation and aquifer layer is highly influenced by aquifer characteristics viz. porosity, permeability and transmissivity, interconnectivity, rock types exposed to the surface and subsurface water sources. Geomorphology play important role to controls groundwater's surface and subsurface movement (Muralitharan and Palanivel, 2015; Kumar and Krishna, 2018). Lineaments serve as ducts for the downward percolation of water. Its attendance generally denotes a permeable zone. Areas round lineaments and their joint point are favourable sites for groundwater storage due to the high infiltration rate (Mukherjee and Singh, 2020). Therefore, areas having greater lineament density have more impact on groundwater prospect zones and vice versa. Elevation of a particular region reflects the ruggedness of terrain; it plays an important role in demarcating potential groundwater zones. Areas with low elevation hold water for a longer duration, inducing more infiltration of recharge water and generate less runoff in case of adequate rainfall and lower evapotranspiration. In divergence, an area with higher elevation holds rainwater for a lesser duration and generates more runoff. Slope gradient play a key role of controls infiltration and surface runoff rate. Steep slopes produce less recharge because of high surface runoff, provided that insufficient time to infiltrate associated to mild/gentle slope wherein the surface runoff is slow, allowing more time for rainwater to percolate (Ghosh et al., 2016). LULC impacts groundwater recharge, soil moisture of a region. Forests, water bodies are good groundwater foundations. In contrast, barren lands, rocky surfaces, built-up land are a poor source of groundwater manifestation due to low permeability, high surface runoff. Groundwater recharge straight varies with the amount of rainfall. Long duration, low-intensity rainfall is ideal for groundwater recharge, as it does not yield high surface runoff and provides sufficient time for water to percolate down. Soil structure and texture control the rate of infiltration, percolation, permeability (Jasrotia et al., 2016). Drainage density specifies the balance between the rate of surface runoff and groundwater infiltration. High drainage density indicates greater headward erosion, low permeability, greater runoff, low infiltration, low drainage density leads to coarse drainage texture, less erosion, more infiltration, a higher probability of recharge.

\section{STUDY AREA}

Amravati River is an important tributary of Tapi River system, flowing through Maharashtra States. It originates from fringes of Sahyadri range, $650 \mathrm{~m}$ above mean sea level west of Deccan plateau in Dhule District, Maharashtra. It flows $57.73 \mathrm{kms}$ eastwards and joins Tapi River at Shendvade in Dhule District, Maharashtra. The study basin extends between Latitudes $21^{\circ} 09^{\prime} 44^{\prime \prime}$ to $21^{\circ} 24^{\prime} 42^{\prime \prime}$ ' $\mathrm{N}$ and Longitudes $74^{\circ} 12^{\prime} 55^{\prime}$ ' to $74^{\circ} 44^{\prime} 06^{\prime}$ ' E. spanning an area of 795 sq. km (Fig. 1).

\section{MATERIALS AND METHOD}

\subsection{Data acquisition \& preparation of thematic layers}

Several thematic layers are prepared using remote sensing and GIS. Base map is prepared from Survey of India Toposheet on 1:50,000 scale. Drainage density, relief, slope maps are equipped from available $30 \mathrm{~m}$ SRTM DEM using ArcGIS 10.8.1. Land use map is generated from ASTER and Landsat 8 OLI satellite image, October 2020, through unsupervised classification using k means classifier. The geological map is digitized from Geological Quadrangle maps of Geological Survey of India. Geomorphology, and Lineament maps are obtained from ASTER and Landsat 8 OLI satellite image. Lineament density map is prepared after updating the Lineament map using remote sensing data and drainage map. A soil map is prepared from soil survey of India data and a rainfall map from IMD, Pune rainfall data.

\subsection{Weighting and rating of layers}

Diverse parameters and their subclasses apply varying influence on the behaviour of underground water and hence have to be rated and weighed in a different way. In the present study, this is done using Multi-Criteria Decision Analysis technique based on Analytical Hierarchy Process (AHP), an approach simplifying decision making by organizing perception, judgments into a multi-level hierarchical structure based on a pair-wise comparison of the importance of different criteria and sub-criteria through the following steps: (i) defining the main problem (ii) Variable selection (iii) decisive the relative scale weights of selected variable through subjective judgment based on expert opinion on Saaty's rating scale of 1-9 (Table 1). (iv) put on pairwise comparison to generate comparison matrices to compute the geometric mean and standard weights (v) calculating inconsistency index and consistency ratio $(\mathrm{Cr})$ for measuring the level of inconsistency. If the value of Consistency Ratio $(\mathrm{Cr})$ 0.1, inconsistency is acceptable else revision of subjective judgment is made (Saaty, 1990). In the present study, the value of Consistency Ratio 0.1 for all thematic layers; hence inconsistency is acceptable (Tables 3). (vi) finding and applying overall derived weights to variables. 
Vol. 8, Issue 11, November 2021

DOI: $10.17148 /$ IARJSET.2021.81115

Table 1 Scale of preferences for the pairwise comparison.

\begin{tabular}{|l|l|}
\hline Intensity of Importance & Definitions \\
\hline 1 & Equally important \\
\hline 2 & Equally to moderately important \\
\hline 3 & Moderately important \\
\hline 4 & Moderately to strongly important \\
\hline 5 & Strongly important \\
\hline 6 & Strongly to very strongly important \\
\hline 7 & Very strongly important \\
\hline 8 & Very strongly to extremely important \\
\hline 9 & Extremely important \\
\hline
\end{tabular}

\subsection{Sensitivity analysis}

To recognize influential thematic layers of obtained Groundwater Potential Zones and the influence of assigned ranks and weights to each class and thematise layer, a sensitivity analysis using the map removal method is carried out (Kindie et al., 2019). It indicates which map is most or least critical in determining values of the output map. In it, one theme at a time is removed, and Groundwater Potential Zones recalculated with remaining themes; sensitivity of removed theme is then computed.

Table 2: Pairwise comparison matrix of nine thematic layers $(\mathrm{CI}=\mathbf{0 . 0 4 8 7 5}, \mathrm{Cr}=\mathbf{0 . 0 3 3 6})$.

\begin{tabular}{|l|l|l|l|l|l|l|l|l|l|l|l|}
\hline Layers & GG & LD & GM & SL & LULC & SO & RL & RF & DD & GM & FW \\
\hline GG & 1 & 2 & 3 & 4 & 5 & 6 & 7 & 8 & 9 & 4.14 & 0.31 \\
\hline LD & 0.5 & 1 & 2 & 3 & 4 & 5 & 6 & 7 & 8 & 3.00 & 0.22 \\
\hline GM & 0.33 & 0.5 & 1 & 2 & 3 & 4 & 5 & 6 & 7 & 2.11 & 0.16 \\
\hline SL & 0.25 & 0.33 & 0.5 & 1 & 2 & 3 & 4 & 5 & 6 & 1.46 & 0.11 \\
\hline LULC & 0.2 & 0.25 & 0.33 & 0.5 & 1 & 2 & 3 & 4 & 5 & 1.00 & 0.07 \\
\hline SO & 0.166 & 0.2 & 0.25 & 0.33 & 0.5 & 1 & 2 & 3 & 4 & 0.68 & 0.05 \\
\hline RL & 0.142 & 0.166 & 0.2 & 0.25 & 0.33 & 0.5 & 1 & 2 & 3 & 0.47 & 0.04 \\
\hline RF & 0.125 & 0.142 & 0.166 & 0.2 & 0.25 & 0.33 & 0.5 & 1 & 2 & 0.33 & 0.02 \\
\hline DD & 0.111 & 0.125 & 0.142 & 0.166 & 0.2 & 0.25 & 0.33 & 0.5 & 1 & 0.24 & 0.02 \\
\hline
\end{tabular}

GG = Geology, LD = Lineament Density, GM = Geomorphology, SL = Slope,

LULC = land use, $\mathrm{SO}=$ Soil, $\mathrm{RL}=$ Relief, $\mathrm{RF}=$ Rainfall, $\mathrm{DD}=$ Drainage density

\section{RESULTS AND DISCUSSION}

\subsection{Assignment of weights}

Table 2 shows the pairwise comparison matrix of nine selected variables and their relative weights. Weights have been allocated, taking into consideration the relative influence of each variable on groundwater potential through particular judgment based on expert opinion and literature review. Maximum weight is assigned to geology and minimum weight to relief, drainage density.

\subsection{Geology}

Geologically, the study basin is part of Deccan plateau composed of formations of basalt, dolerite and alluvial by major regional and several local unconformities. Alluvium $275.33 \mathrm{~km}^{2}$ is concentrated in the north at the confluence of Amravati with Tapi river. To its south lie dolerite $3.51 \mathrm{~km}^{2}$ and basalt $616.16 \mathrm{~km}^{2}$ occupy the western parts. According to rock characteristics, high weight is assigned to alluvium. Groundwater prospects within these formations are high, depth to water varies from 1.5 to $4 \mathrm{~m}$ with good yield. Moderate and low weight is assigned to dolerite and basalt.

\subsection{Geomorphology}

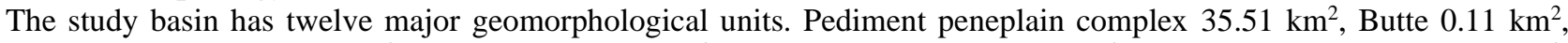
Dyke/ Sill ridge $17.438 \mathrm{~km}^{2}$, Pediment $143.09 \mathrm{~km}^{2}$, Active flood plain $0.09 \mathrm{~km}^{2}$, Older alluvial plain $91.90 \mathrm{~km}$, Gullied land $12.13 \mathrm{~km}^{2}$, Pediplain $400.14 \mathrm{~km}^{2}$, Plateau Remnant $63.08 \mathrm{~km}^{2}$, Moderately Dissected Lower Plateau 11.48 $\mathrm{km}^{2}$, and valleys $1.77 \mathrm{~km}^{2}$. Pediment peneplain complex is a slightly sloping weathered rock surface characterized by 


\title{
International Advanced Research Journal in Science, Engineering and Technology
}

\author{
Vol. 8, Issue 11, November 2021
}

\section{DOI: $10.17148 /$ IARJSET.2021.81115}

low relief; numerous fractures and joints are formed due to laminar sheet flow of water, measured good for groundwater movements and storage (Deepika et al. 2013). Old and active flood plains are low land flat plains, fluvial in origin with good groundwater prospects. Structural and denudational hills are dissected hills that act as runoff zones due to their hard rock and compact nature with very limited infiltration possibilities and have low groundwater prospects. Therefore, active and old flood plains \& pediment peneplain complex have been given high weightage as compared to structural and denudational hills.

\subsection{Lineament density}

Lineaments are ducts for water to infiltrate in the ground. Numerous lineaments are found across the basin, especially in basalt formations, they deliver secondary porosity for water to circulate through aquifers. They mainly present in the western, southern, southeastern and northewestern and central parts of the basin. Most of these lineament's trend in the east, and north direction (Fig.), their density varies between $0.1 \mathrm{~km} / \mathrm{km}^{2}$ to $3.70 \mathrm{~km} / \mathrm{km}^{2}$. From density point of view greater part of the basin has very low lineament density, only $5.39 \%$ has a very high density of $>1 \mathrm{~km} / \mathrm{km}$. Lineaments and their intersections are considered favourable for groundwater storage and the intensity of groundwater decreases with remoteness from lineaments (Kindie et al., 2019) hence high weightage is given to high-density zones and low weight to low-density zones.

\subsection{Relief}

Relief in the study basin varies from $119 \mathrm{~m}$ to $650 \mathrm{~m}$ elevation. Most of the basin (65\%), except south, has low to very low relief, thus representing good groundwater potential scenarios. However, its concrete position depends upon the impact of the other eight factors taken into consideration. Consequently, maximum weight is assigned to very low relief that decreases with increasing elevation.

\subsection{Slope}

The slope in the basin varies from 0 to 33 degree. It has been reclassified into five classes less than 3-degree (very gentle), 3-7-degree (gentle), 7- 13-degree (moderate), 13-22-degree (steep) and greater than 22-degree (very steep) classes, based on FAO classification. The greater part of the basin $(58.8 \%)$ has very gentle to gentle slope. Areas characterized with steep $4.84 \%$ and very steep $1.34 \%$ slopes are mainly found in the southern part of the basin. Higher weight is assigned to gentle and very gentle slope area as there are low runoff and larger residence time for water to percolate down, lower weights are assigned to steep and very steep slope areas signifying high runoff and low infiltration.

\subsection{Rainfall}

The Amravati basin lies in the arid tropical climat. The average annual rainfall of the basin, based on 30 years average is estimated between $564 \mathrm{~mm}$ and $686 \mathrm{~mm}$. The central part of the basin receives moderate to very low rainfall whereas extreme western parts receive high to very high rainfall. Since groundwater potential varies directly with rainfall, maximum weight is assigned to very high rainfall zones and very low weight to very low rainfall zones.

\begin{abstract}
4.8. Land use
Land use is a significant indicator of groundwater potential zones. Forests, water bodies, agricultural land are good sources of groundwater, built-up land, barren land are poor sources. Five major land use types Forests $127.2 \mathrm{~km}^{2}$, Water bodies $31.8 \mathrm{~km}^{2}$, Agricultural land $572.4 \mathrm{~km}^{2}$, Barren land $7.95 \mathrm{~km}^{2}$ and Built-Up Land $55.65 \mathrm{~km}^{2}$ are identified in the Amravati basin. Barren land having extent is located in southern and western parts of the basin. Forests are concentrated in southern and western parts; small patches occur in the southeast. Agricultural land is widely scattered, its major concentration is in the southwest, west, central, northeast and eastern part of the basin. Built- up land mainly comprises Dondaicha town and some villages. Water bodies include Amravati River and Reservoirs. Water bodies are allocated maximum weight as they are principal recharge zones followed by forests, croplands, barren land and built-up land, with very low permeability and infiltration capacity, have the least weightage.
\end{abstract}

\subsection{Soil}

The study area has three four soil types Deep black soil (22.39\%), medium black soil (41.31\%), shallow black soil $(23.14 \%)$, remaining $(13.16 \%)$ area is occupied by red sandy soil. Soils with Deep and medium black soil content provide adequate space for rainwater to get recharged through the land surface, it has good prospects of groundwater potential as compared to shallow black and red sandy soil. Hence Deep and medium black soil have been assigned higher weights than shallow black and red sandy soil. 


\subsection{Drainage density}

Drainage density is total length of unit area streams per unit drainage area. High drainage density values are favourable for runoff and hence designate low groundwater potential zone and vice-versa. Drainage density of the study basin is categorized into very low $\left(0-1 \mathrm{~km} / \mathrm{km}^{2}\right) 42.61 \mathrm{~km}^{2}(5.36 \%)$, low $\left(1-2 \mathrm{~km} / \mathrm{km}^{2}\right) 89.28 \mathrm{~km}^{2}(11.23 \%)$, moderate $(2-$ $\left.3 \mathrm{~km} / \mathrm{km}^{2}\right) 351.15 \mathrm{~km}^{2}(44.17 \%)$, high $\left(3-4 \mathrm{~km} / \mathrm{km}^{2}\right) 187.22 \mathrm{~km}^{2}(23.55 \%)$, very high $\left(4-5 \mathrm{~km} / \mathrm{km}^{2}\right) 124.74 \mathrm{~km} 2$ $(15.69 \%)$ categories. $16.59 \%$ basin area has low to very low drainage density and has been assigned high weight.

\subsection{Ground water potential Zones}

Table 3 Ground water potential Zones of Amravati basin.

\begin{tabular}{|l|l|l|}
\hline Category & Area $\left(\mathbf{k m}^{\mathbf{2}}\right)$ & Area $(\%)$ \\
\hline Very Good & 117.304 & 14.76 \\
\hline Good & 124.827 & 15.70 \\
\hline Moderate & 169.883 & 21.37 \\
\hline Poor & 212.631 & 26.75 \\
\hline Very Poor & 170.355 & 21.43 \\
\hline Total & 795 & 100 \\
\hline
\end{tabular}

Ground water potential Zones based on the computed composite weighted index Amravati basin has been categorized into five zones Very Poor, Poor, Moderate, Good and Very Good groundwater potential zones (Table 3 \& Fig.). The area under very poor groundwater potential is $170.355 \mathrm{~km}^{2}(21.43 \%)$, located mainly in the southern, western and south-eastern parts characterized by vast expanse of very sparsely vegetated low dissected hills and plateaus underlain by dolorite and basalt rock formations, poorly cultivated area, low rainfall. Area under poor groundwater potential $212.631 \mathrm{~km}^{2}(26.75 \%)$ interacted with very poor Ground water potential Zones is scattered all around the basin with major concentration in the southrn part. Geomorphologically, this region is part of the pediment peneplain complex, Plateau Remnant and Moderately Dissected Lower Plateau considered good for groundwater potential however, the presence of hard igneous rocks with very low porosity and permeability, low average rainfall and patches of barren land make it poor groundwater potential zone. Moderate zone $169.883 \mathrm{~km}^{2}(21.37 \%)$ area mainly occurs in the central, south and southwestern region composed of hard igneous rocks formations, extensive cropland, receiving moderate to high rainfall and undergone phased tectonic activity resulting into the development of faults and fractures. Its presence as small patches in the regions of very poor and poor groundwater potential zones where high lineament density and dense forest cover exists. Around reservoir areas is the most extensive zone of good and very good groundwater potential. To another place they occur in small patches along faults, fractures, cultivated areas and densely forested area. They together account for $242.131 \mathrm{~km}^{2}(30.46 \%)$ area.

\subsection{Sensitivity analysis of groundwater potential map}

Sensitivity analysis is significant to know each factor's influence on the groundwater potential map (Mukherjee and Singh, 2020; Fenta et al., 2014; Kindie et al., 2019). The result of sensitivity analysis computed by removing one thematic layer at a time. Higher variation index values were found after removal of the geological thematic layer (mean variation index $=14.31 \%$ ) and geomorphology $(13.06 \%)$, implying that geology and geomorphology are the most sensitive parameters, followed by lineament density (12.23\%), soil (11.01\%), and relief (11.13\%). LULC (10.68\%) and drainage density $(10.42 \%)$ are moderately sensitive whereas rainfall $(9.31 \%)$ and slope $(7.85 \%)$ are least sensitive parameters. In other words, geology and geomorphology applied maximum influence, whereas rainfall and slope have the least influence on groundwater potential in the study area.

\section{CONCLUSIONS}

In the present study, groundwater potential zones in Amravati Basin have been delineated using geospatial technology and Analytical Hierarchical Process. Based on the literature review and experts' opinion, nine parameters viz. geology, lineament density, geomorphology, soil, rainfall, drainage density, slope, relief, LULC have been measured, various thematic layers generated using remote sensing data in ArcGIS 10.8.1. Satty's multi-criteria evaluation is used for the computation of weights of different features and thematic layers. On the basis of the composite score obtained after aggregating thematic layers, the basin is classified into very poor, poor, moderate, good, very good groundwater potential zones. The bulk of the basin $(48.17 \%$ area) lies in very poor, poor groundwater potential zones, moderate zone occurs in $21.37 \%$ area, good and very good groundwater potential zone occur in $30.46 \%$ of the area. To understand the relative importance of various parameters a map removal sensitivity analysis is performed. Geology, geomorphology, lineament density are the three most influential parameters, rainfall and slope are the least influential. 


\title{
International Advanced Research Journal in Science, Engineering and Technology
}

\author{
Vol. 8, Issue 11, November 2021
}

DOI: $10.17148 /$ IARJSET.2021.81115

Overall, remote sensing, GIS, and AHP technique deliver hypothetically powerful tools for studying the groundwater potential, the final map obtained can be used for sustainable development of groundwater in the Amravati basin.

\section{REFERENCES}

Arulbalaji, P., Padmalal, D., Sreelash, K. 2019. GIS and AHP techniques-based delineation of groundwater potential zones: a case study from southern Western Ghats India. Sci. Rep., 9. 10.1038/s41598-019-38567-x.

Agone V. 2014. Hydrogeomorphic Analysis of Tittur Drainage Basin, Lambert Academic Publishing.Germany. ISBN-13: 978-3659646188

Biswas, S.K. 1999. A Review on the evolution of rift basins in India during Gondwana with special reference to Western Indian basins and their hydrocarbon prospects. In: Ashok Sahni and R.S. Loyal (Eds.), Gondwana Assembly: New issues and Perspectives. Indian Natl. Sci, Acad., New Delhi, pp: 53-76.

Dar, T., Rai, N., Bhat, A. 2020. Delineation of potential groundwater recharge zones using analytical hierarchy process (AHP), Geol. Ecol. Landscapes, DOI: 10.1080/ 24749508.2020.1726562.

Deepika, B., Kumar, A., Jayappa, K. 2013. Integration of hydrological factors and demarcation of groundwater prospect zones: Insights from remote sensing and GIS techniques. Environ. Earth Sci. 70. pp: 1319-1338. DOI. 10.1007/s12665- 013-2218-1.

Fenta, A.A., Kifle, A., Gebreyohannes, T., Hailu, G. 2014. Spatial analysis of groundwater potential using remote sensing and GIS-based multicriteria evaluation in Raya Valley, northern Ethiopia. Hydrogeol. J. 23, 195-206. 10.1007/s10040-014-1198-x.

Ghosh, P.K., Bandyopadhyay, S., Jana, N.C., 2016. Mapping of groundwater potential zones in hard rock terrain using geoinformatics: a case of Kumari watershed in western part of West Bengal. Model Earth Syst. Environ. 2 (1), 1. https://doi.org/ 10.1007/s40808-015-0044-z.

Gnanachandrasamy, G., Zhou, Y., Bagyaraj, M., Venkatramanan, S., Ramkumar, T., Wang, S., 2018. Remote sensing and GIS based groundwater potential zone mapping in Ariyalur District, Tamil Nadu. J Geol Soc India 92 (4), 484-490. https://doi.org/10.1007/s12594-018-1046-z.

Jasrotia, A.S., Kumar, A., Singh, R., 2016. Integrated remote sensing and GIS approach for delineation of groundwater potential zones using aquifer parameters in Devak and Rui watershed of Jammu and Kashmir, India. Arab. J. Geosci. 9 (4), 1-15. https://doi.org/10.1007/s12517-016-2326-9.

Kindie, A.T., Enku, T., Moges, M.A., Geremew, B.S., Atinkut H.B. 2019. Spatial Analysis of Groundwater Potential Using GIS Based Multi Criteria Decision Analysis Method in Lake Tana Basin, Ethiopia. in: Zimale F., et.al. (eds) Advances of Science and Technology. ICAST 2018. Lecture Notes of the Institute for Computer Sciences, Social Informatics and Telecommunications Engineering, vol. 274. Springer, Cham. 10.1007/978-3030-15357-1_37.

Kumar, A. and Krishna, A.P., 2018. Assessment of groundwater potential zones in coal mining impacted hard-rock terrain of India by integrating geospatial and analytic hierarchy process (AHP) approach. Geocarto Int. 33 (2), pp: 105-129. 10.1080/10106049.2016.1232314.

Kumar, S., Machiwal, D., Parmar B.S. 2019. A parsimonious approach to delineating groundwater potential zones using geospatial modeling and multi-criteria decision analysis techniques under limited data availability condition, Eng. Rep. e12073. 10.1002/eng2.12073.

Mallick, J., Khan, R.A., Ahmed, M., Alqadhi, S. D. et.al. 2019. Modeling groundwater potential zone in asemi-arid region of Aseer using fuzzy-AHP and Geoinformation Techniques. Water, 11(2656); doi:10.3390/w11122656.

Mukherjee and, I., Singh, U.K., 2020. Delineation of groundwater potential zones in a drought-prone semi-arid region of east India using GIS and analytical hierarchical process techniques. J. Catena. 194, 104681. https://doi.org/10.1016/j.catena.2020.104681.

Muralitharan and, J., Palanivel, K., 2015. Groundwater targeting using remote sensing, geographical information system and analytical hierarchy process method in hard rock aquifer system, Karur district, Tamil Nadu, India. Earth Sci Inform 8 (pp), 827-842. https://doi.org/10.1007/s12145015-0213-7.

Murmu, P., Kumar, M., Lal, D., Sonker, I., Singh, S.K., 2019. Delineation of groundwater potential zones using geospatial techniques and analytical hierarchy process in Dumka district, Jharkhand, India. J. Groundw. Sustain. Dev. 9, 1-16. https://doi.org/10.1016/j.gsd.2019.100239.

Niti Aayog Report, 2018. Composite Water Management Index. Niti Aayog, Government of India, New Delhi.

Rajasekhar, M., Sudarsana Raju, G., Sreenivasulu, Y., Siddi Raju, R., 2019. Delineation of groundwater potential zones in semi-arid region of Jilledubanderu river basin, Anantapur District, Andhra Pradesh, India using fuzzy logic, AHP and integrated fuzzy-AHP approaches. Hydro Res. 2, 97-108.

Roy, A., Keesari, T., Sinha, U.K, Sabrathinam, C. 2019. Delineating groundwater prospect zones in a region with extreme climatic conditions using GIS and remote sensing techniques: A case study from central India. J. Earth Syst. Sci. Indian Acad. Sci. 128(201) 10.1007/s12040-019-1205-7.

Saha D., Ray R.K. 2019. Groundwater Resources of India: Potential, Challenges and Management. In: Sikdar,P. (eds)Groundwater Development and Management. Springer, Cham. 10.1007/978-3-319-75115-3_2.

Saaty, T.L., 1980. The Analytic Hierarchy Process. McGraw Hill, New York.

Saaty, T.L., 1990. How to make a decision: The analytic hierarchy process. European Journal of Operational Research 48 (1), 9-26. https://doi.org/10.1016/0377-2217(90)90057-I.

Yeh, H.F., Cheng, Y.S., Lin, H.I., Lee, C.H. 2016. Mapping groundwater recharge potential zone using a GIS approach in Hualian River, Taiwan. Sustain. Environ. Res., 26(1), pp: 33-43. 10.1016/j.serj.2015.09.005.

N. Verma and Ramesh Kumar Patel, 2021 Delineation of groundwater potential zones in lower Rihand River Basin, India using geospatial techniques and AHP, The Egyptian Journal of Remote Sensing and Space Sciences, https://doi.org/10.1016/j. ejrs.2021.03.005 